\title{
Ultraviolet-B radiation and bacterial metabolism in coastal waters
}

\author{
Gerald Müller-Niklas ${ }^{1}$, Andreas Heissenberger ${ }^{1}$, Stasa Puškarić ${ }^{2}$, \\ Gerhard J. Herndl ${ }^{1, *}$ \\ ${ }^{1}$ Institute of Zoology, University of Vienna, Althanstr. 14, A-1090 Vienna, Austria \\ ${ }^{2}$ Ruđer Boskovič Institute, Center for Marine Research Rovinj, 52210 Rovinj, Croatia
}

\begin{abstract}
The impact of ultraviolet-B (UV-B) radiation on bacterial density and production and on extracellular enzymatic activity was investigated the northern Adriatic Sea. Samples were incubated in quartz bottles and exposed to natural solar radiation $\left(0.5 \mathrm{~W} \mathrm{~m}^{-2}\right)$ as well as to artificial UV-B $\left(0.4 \mathrm{~W} \mathrm{~m} \mathrm{~m}^{-2}\right)$ sources. Exposure to artificial UV-B sources over a period of $12 \mathrm{~h}$ revealed a constant decline in bacterial density to about $60 \%$ of the corresponding dark value. Total lipase and leucine-aminopeptidase activity showed a decrease to 38.8 and $21.9 \%$, respectively, of the dark control; dissolved leucineaminopeptidase activity was significantly more affected (15.3\% of the corresponding dark value) than dissolved lipase activity ( $43.2 \%$ of the corresponding dark value). Samples exposed for $6 \mathrm{~h}$ to artificial UV-B or for $4 \mathrm{~h}$ to natural solar radiation exhibited rapid recovery during subsequent dark incubation. Following UV-B exposure $\left(0.4 \mathrm{~W} \mathrm{~m}^{-2}\right)$ bacterial density recovered rapidly from $74.6 \%$ to $84.1 \%$, lipase activity recovered from $64 \%$ to $80 \%$ and leucine-aminopeptidase activity from $53 \%$ to $71 \%$ of the corresponding dark values during $6 \mathrm{~h}$ of subsequent dark incubation. Recovery of bacteria following exposure to natural solar UV-B radiation with similar intensity was even higher. In these experiments bacterial density reached similar values as in the dark control, bacterial production even exceeded the dark control production rates after $6 \mathrm{~h}$ of dark incubation following UV-B exposure. This difference might be attributed to photorepair induced by UV-A and to increased availability of dissolved organic matter due to UV-B mediated photolysis. UV-B radiation levels of $0.4 \mathrm{~W} \mathrm{~m}^{-2}$ as used in this study are detectable in the surface layers of the northern Adriatic Sea up to $0.5 \mathrm{~m}$ depth for at least 3 to $5 \mathrm{~h} \mathrm{~d}^{-1}$ during summer. Thus our results suggest that microbial life might be affected by UV-B radiation and consequently also the carbon and energy flow in aquatic systems.
\end{abstract}

KEY WORDS: Ultraviolet-B $\cdot$ Bacteria $\cdot$ Ectoenzymatic activity $\cdot$ Bacterial growth $\cdot$ Northern Adriatic

\section{INTRODUCTION}

Ozone destruction over Antarctica during the polar winter ultimately leads to an increase in ultraviolet- $B$ (UV-B) radiation on the earth's surface (Blumthaler \& Ambach 1990, Crutzen 1992). This increase in UV-B (280 to $320 \mathrm{~nm}$ ) might be harmful not only to humans but to life in general (Smith 1989, Worrest \& Häder 1989, Seckmeyer \& McKenzie 1992, Krupa \& Kickert 1993). Although the damaging effect of UV-B on organisms has been known for quite some time and

\footnotetext{
- Addressee for correspondence;

E-mail: gerhard.herndl@univie.ac.at
}

UV-C $(<280 \mathrm{~nm})$ is frequently used for sterilization purposes in laboratories or to photolytically cleave complex macromolecules, the ecological impact of UV-B on aquatic ecosystems remains to be elucidated (Karentz et al. 1994).

During the last decade a new concept on the structure of aquatic food webs emerged (Azam et al. 1983). It is now believed that heterotrophic bacteria play a central role in the carbon and energy flux through aquatic systems, converting up to $80 \%$ of the phytoplankton primary production (Fuhrman et al. 1989, Cho \& Azam 1990, Ducklow \& Carlson 1992, Ducklow et al. 1993). This notion placed bacterioplankton in the center of the microbial food web. Therefore, if the 
impact of ultraviolet radiation on carbon and energy flow at an ecosystem level is the matter of interest, one has to focus on microbially mediated processes.

There is some information available on the influence of UV-B on zooplankton and phytoplankton, including flagellates (Worrest \& Häder 1989, Häder \& Liu 1990, Cullen \& Lesser 1991, Ekelund 1991, Cullen et al. 1992, Helbling et al. 1992, Smith \& Buddemeier 1992, Tirlapur et al. 1993, Karentz et al. 1994). Our information on the impact of UV-B on bacteria and dissolved organic matter (DOM) cycling is rather scarce (Bailey et al. 1983, Akhlaq et al. 1990, Karentz et al. 1991, Backlund 1992, Herndl et al. 1993). These are, however, the basic compartments of the microbial loop determining the flux of material and, hence, the overall productivity in aquatic systems. Deviations in the size and structure of these compartments of the microbial food web due to UV-B radiation might be of importance for the structure of the entire food web and also the species composition at higher trophic levels. Due to their high turnover rates microbes should be able to adapt faster to changing environmental conditions than long-living organisms. As shown in a series of papers by Mopper and co-workers, DOM is photolytically cleaved in significant quantities making low molecular weight compounds potentially available for microbial uptake (Mopper \& Stahovec 1986, Kieber \& Mopper 1987. Kieber et al. 1989, Mopper et al. 1991).

In this paper we aimed to determine the penetration of UV-B into the water column in coastal waters in order to obtain more detailed information on the influence of ultraviolet radiation on extracellular enzymatic activity and growth of bacterioplankton. Both parameters, bacterial growth and extracellular enzymatic activity, measure indirectly the processing of DOM. Leucine aminopeptidase and lipase were used because they are known to be of mainly bacterial origin. Since most of the energy and material in pelagic systems is channeled through bacteria, any potential effect of UV-B on bacteria leads ultimately to changes in the productivity of the overall system.

\section{MATERIALS AND METHODS}

Study sites. In situ measurements on UV-B penetration and bacterial activity were performed in the northern Adriatic Sea $\left(45^{\circ} 05^{\prime} \mathrm{N}, 13^{\circ} 30^{\prime} \mathrm{E}\right)$ about $1 \mathrm{~km}$ off the Center for Marine Research at the Ruđer Boskovic Institute at Rovinj (Croatia) from July 1991 to July 1993.

UV-B measurements. UV-B penetration into the water column was performed using a semiconductor ultraviolet sensor (G3614-01 Hamamatsu) with a cutoff at the lower end of the spectrum at $260 \mathrm{~nm}$ and at the upper end of the spectrum at $320 \mathrm{~nm}$, with a peak response at $290 \mathrm{~nm}$. Since no light below $300 \mathrm{~nm}$ reaches the Earth's surface the lower end of the spectrum measured did not affect our measurements. In the laboratory experiments, the wavelength spectrum of the lamps used ranged from 300 to $650 \mathrm{~nm}$. The emitted spectrum was measured using an Oriel Intaspec II.

Exposure of bacterioplankton to UV-B. Water samples were collected from depths ranging between 0.5 and $2 \mathrm{~m}$ in $\mathrm{HCl}$-rinsed Niskin bottles about $1 \mathrm{~km}$ off the Center for Marine Research at Rovinj and brought to the laboratory within $30 \mathrm{~min}$. There they were exposed to natural solar radiation at in situ temperature by transferring water into $\mathrm{HCl}$-rinsed quartz bottles, and bacterial density and production and extracellular enzymatic activity were measured as described below. In situ temperature was maintained by a running water system. During the course of incubation UV-B radiation was measured at $5 \mathrm{~min}$ intervals. Since the incubations were only performed on cloudless days around noon for a maximum time of $4 \mathrm{~h}$, variations in the intensity of the UV-B radiation during the course of incubations were generally $<20 \%$.

Laboratory experiments were performed to investigate the role of different dose rates of UV-B on bacterial density and extracellular enzymatic activity. Raw and $0.2 \mu \mathrm{m}$ double-filtered (Millipore, polycarbonate) seawater from the sampling site was exposed to artificial UV-B radiation (Philips, UV-B TL 100 W/01; emission peak at $311 \mathrm{~nm}$ ) at an intensity of $0.4 \mathrm{~W} \mathrm{~m}^{-2}$ in $100 \mathrm{ml}$ quartz flasks for 6 and $12 \mathrm{~h}$, respectively; the flask exposed to UV-B for $6 \mathrm{~h}$ was held in the dark for another $6 h_{i}$ a control flask was kept in continuous darkness for $12 \mathrm{~h}$. To investigate the influence of UV-B on dissolved enzymes, $0.2 \mu \mathrm{m}$ double-filtered seawater was exposed to UV-B radiation for $12 \mathrm{~h}$ with a dark control. All flasks were kept at $18^{\circ} \mathrm{C}$. Thereafter, bacterial density (also in the $0.2 \mu \mathrm{m}$ filtrate to check for bacterial growth) and ectoenzymatic activity were determined in the raw and $0.2 \mu \mathrm{m}$ filtered seawater every $3 \mathrm{~h}$ for a total of $12 \mathrm{~h}$.

All the measurements described below were performed before and after UV-B exposure and at the end of the subsequent dark incubation. Thus the problem of exposing labeled thymidine and fluorogenic substrates to UV-B radiation was avoided.

Determination of bacterial density. Bacterial density was determined using the acridine orange direct counting technique (Hobbie et al. 1977). Enumeration of bacteria was done with a Leitz Laborlux S equipped with an epifluorescence unit as outlined in Karner \& Herndl (1992). To convert bacterial density into carbon equivalents we assumed a carbon content of $20 \mathrm{fg} \mathrm{C}$ cell-1 $^{-1}$ (Lee \& Fuhrman 1987)

Determination of bacterial production. Bacterial production was measured by the $\left[{ }^{3} \mathrm{H}\right]$-thymidine (spe- 
cific activity $85 \mathrm{Ci} \mathrm{mmol}^{-1}$, Amersham) incorporation technique (Fuhrman \& Azam 1982). We added thymidine to $5 \mathrm{ml}$ of water, to obtain a final concentration of $10 \mathrm{nM}$ which was found sufficient to saturate bacterial uptake systems. After incubation, samples were filtered onto $0.45 \mu \mathrm{m}$ cellulose membrane filters (Millipore HA, $25 \mathrm{~mm}$ diameter) and rinsed with ice-cold trichloroacetic acid. Subsequently, the filters were placed in scintillation vials, dissolved in $1 \mathrm{ml}$ of ethylacetate and $8 \mathrm{ml}$ of scintillation cocktail (Insta-Gel, Packard) and the radioactivity assessed. A conversion

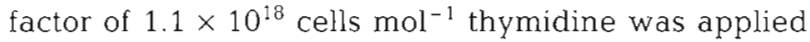
(Fuhrman \& Azam 1982)

Determination of extracellular enzymatic activity. Fluorescent substrate analogs were added to $3 \mathrm{ml}$ of sample (2.5 $\mu \mathrm{M}$ final concentration) according to Hoppe (1983) and incubated at in situ temperature. We measured the release rate of the fluorophore over time, which is proportional to the hydrolytic cleavage of the substrate. Two model substrates were used: 4 methylumbelliferyl butyrate to estimate lipase activity and L-leucine 7-amino-4-methylcoumarin (leu-MCA) to estimate proteolytic activity. All chemicals were purchased from Sigma Chemicals. Hydrolytic activity was calibrated with known amounts of 7 -amino4-fluoromethyl-coumarin (MCA) for leu-MCA and 4methylumbelliferone (MU) for the other substrate. Fluorescence was measured with a Jasco 820-FP spectrofluorometer using a sample blank and an emission wavelength of $440 \mathrm{~nm}$ and an excitation set at $360 \mathrm{~nm}$. Incubation period was ca $30 \mathrm{~min}$.

\section{RESULTS}

\section{UV-B penetration into the water column of coastal waters}

Surface solar UV-B radiation on a cloudless, clear day in the northern Adriatic Sea is given in Fig. 1

\section{Bacterial density and production}

Prolonged exposure of bacteria to natural as well as artificial UV-B $\left(0.4 \mathrm{~W} \mathrm{~m}^{-2}\right)$ led to a reduction in bacterial abundance (Fig. 2A). When exposed to artificial UV-B, bacterial density declined to $74 \%$ of the corresponding dark value after $6 \mathrm{~h}$ and to $57 \%$ after $12 \mathrm{~h}$ (Fig. 2A). After an exposure of $4 \mathrm{~h}$ to natural UV-B radiation $\left(0.5 \mathrm{~W} \mathrm{~m}^{-2}\right)$ bacterial abundance was reduced to $77.4 \%$ of the dark value (Fig. 2A). Bacteria that were kept in the dark after exposure to UV-B recovered as indicated by an increase in bacterial density from $74.6 \%$ to $84.1 \%$ (exposure to artificial UV-B) and from

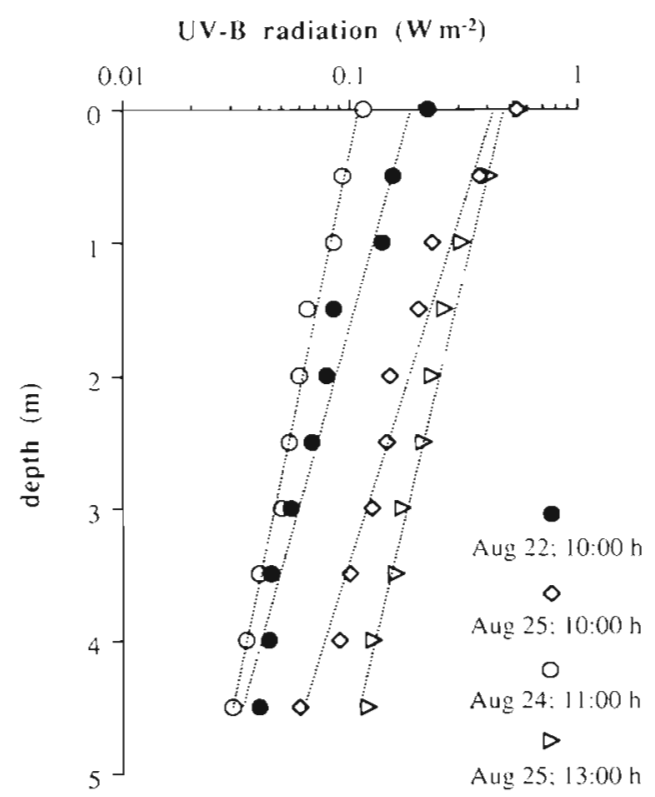

Fig. 1 UV-B penetration into the nearshore water column of the northern Adriatic Sea. Measurements were performed around noon on a cloudless, clear day
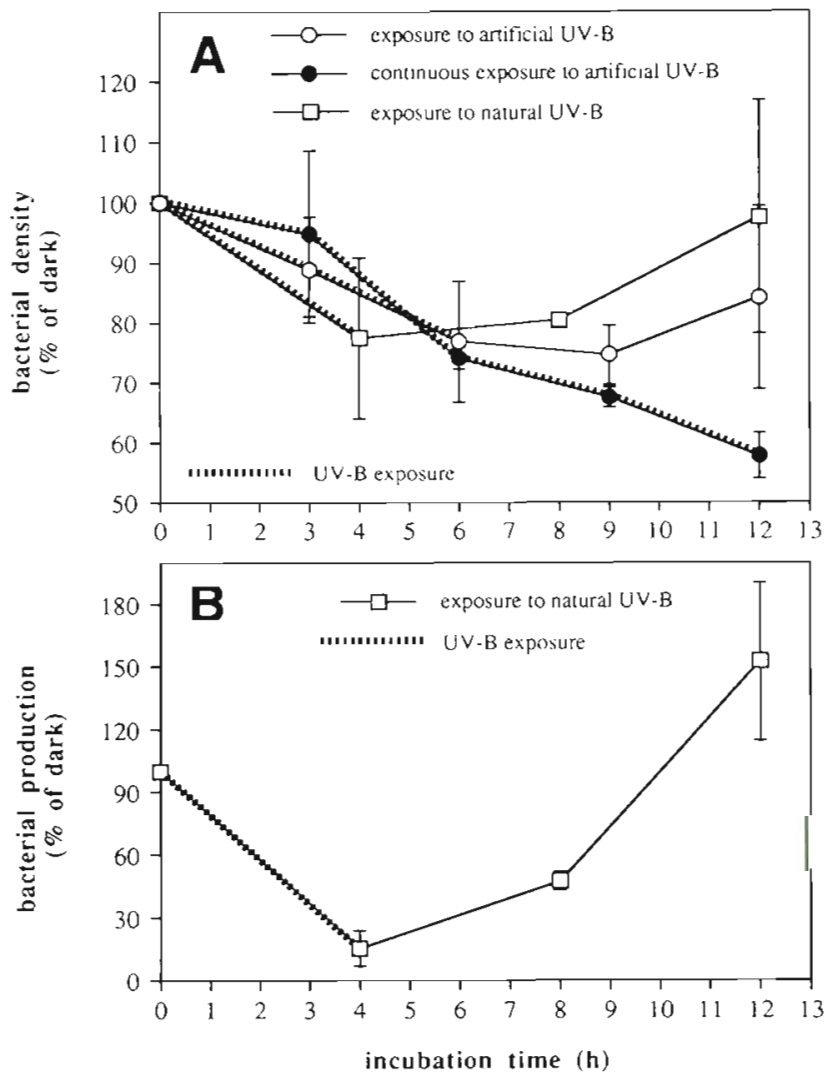

Fig. 2. Influence of natural $\left(0.5 \mathrm{~W} \mathrm{~m}^{-2}\right)$ and artificial UV-B $\left(0.4 \mathrm{~W} \mathrm{~m}^{-2}\right)$ on (A) bacterial density and (B) bacterial production during long-term (12 h) and short-term (4 or $6 \mathrm{~h}$, respectively) incubations 
$77.4 \%$ to $97.5 \%$ (exposure to natural UV-B) of the corresponding dark value, respectively (Fig. 2A). Bacterial production was only $15.3 \%$ of the corresponding dark value after $4 \mathrm{~h}$ of exposure to natural UV-B (Fig. 2B). Bacterial production recovered, however, during the following $8 \mathrm{~h}$ in darkness to $152 \%$ of the bacterial production obtained from the dark incubations.

\section{Bacterial extracellular enzymatic activity}

Exposing $0.2 \mu \mathrm{m}$ double-filtered seawater to artificial UV-B radiation resulted in a significant decrease in dissolved extracellular lipase and leucine-aminopeptidase activity (Fig. 3). An exposure time of $12 \mathrm{~h}$ led to a reduction to about $40 \%$ of the corresponding dark control for dissolved lipase activity and to about $11 \%$ of the dark control for dissolved leucine-aminopeptidase activity (Fig. 3). To estimate the impact of UV-B on the total extracellular enzymatic activity we exposed unfiltered seawater samples to artificial UV-B. After $12 \mathrm{~h}$ of UV-B exposure $\left(0.4 \mathrm{~W} \mathrm{~m}^{-2}\right)$ total lipase activity was reduced to about $40 \%$ and total leucine-aminopeptidase activity to about $20 \%$ of the corresponding dark value (Fig. 4). In another experiment, bacteria were exposed to artificial UV-B $\left(0.4 \mathrm{~W} \mathrm{~m}^{-2}\right)$ for $6 \mathrm{~h}$; leucineaminopeptidase and lipase activity dropped to 53 and $64 \%$ of the corresponding dark control, respectively (Fig. 5). During the following dark incubation for $6 \mathrm{~h}$, lipase activity increased again to $80 \%$ of the dark control and leucine-aminopeptidase activity to $71 \%$. No significant differences could be found between the

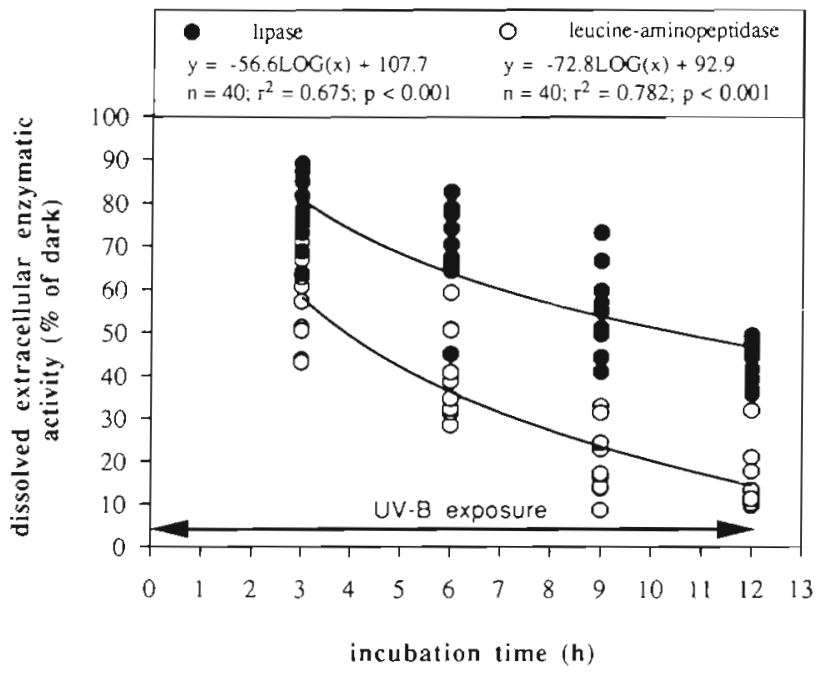

Fig. 3. Impact of artificial UV-B $\left(0.4 \mathrm{~W} \mathrm{~m}^{-2}\right)$ on dissolved lipase and leucine-aminopeptidase activity during an exposure time of $12 \mathrm{~h}$

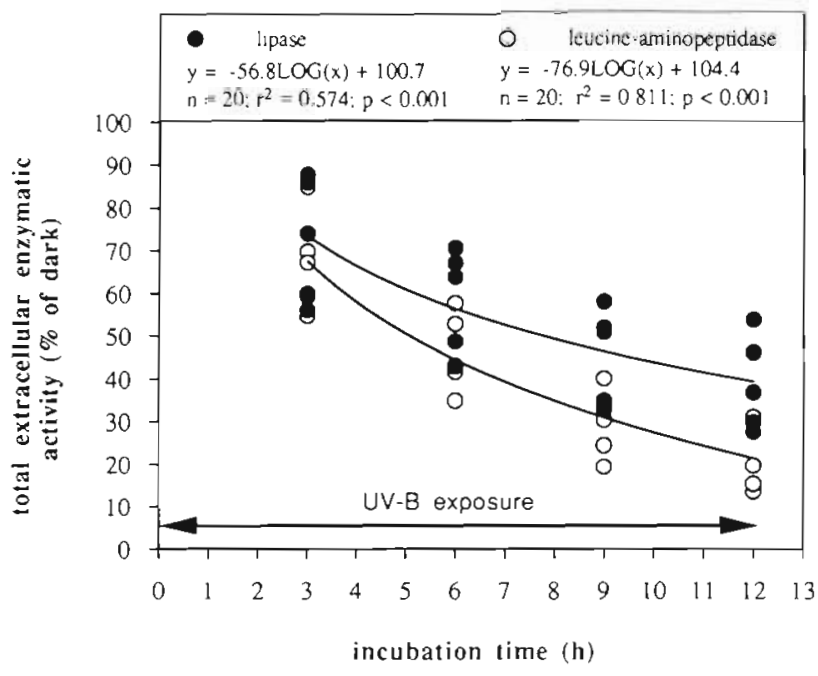

Fig. 4. Impact of artificial UV-B $\left(0.4 \mathrm{~W} \mathrm{~m}^{-2}\right)$ on total lipase and leucine-aminopeptidase activity during an exposure time of $12 \mathrm{~h}$

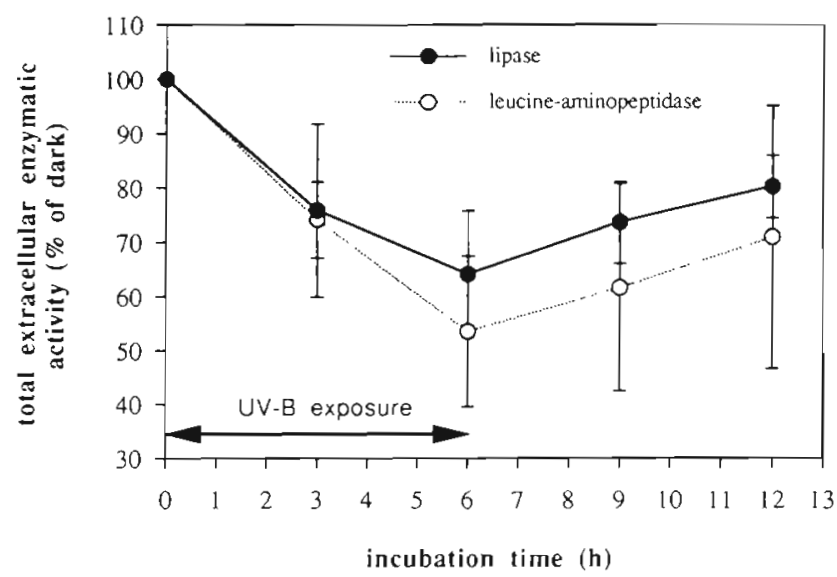

Fig. 5. Rapid recovery of total lipase and leucine-aminopeptidase activity within $6 \mathrm{~h}$ in darkness following an exposure to artificial UV-B $\left(0.4 \mathrm{~W} \mathrm{~m}^{-2}\right)$ for $6 \mathrm{~h}$

reduction of total and dissolved extracellular enzymatic activity either for lipase or for leucine-aminopeptidase during the entire exposure period (Wilcoxon signed-rank test, data not shown); moreover, the reduction of total lipase activity due to UV-B radiation was not significantly different from the reduction in total leucine-aminopeptidase activity (Wilcoxon signed-rank test, data not shown).

\section{DISCUSSION}

Summarizing the scarce data on UV-B penetration into the water column we have reason to assume that UV-B penetrates deeper into the water column than 
previously thought (Jerlov 1950). Therefore, organisms and aquatic food webs might also be more affected by this UV-B radiation than hitherto assumed. In this and a previous paper (Herndl et al. 1993) we have shown that bacterial metabolism is affected by UV-B radiation (Fig. 2A, B). Bacterial density declined slightly when exposed to UV-B, whereas a steady increase was obtained in our dark incubations (data not shown). The development of bacterial density in the different treatments results in a strong decline in bacterial density in the UV-B exposed flasks when expressed as \% of dark values (Fig. 2A). This method of presenting the data enables us to compare results from a series of experiments performed with samples of different water bodies.

Only 1 series of experiments was performed with natural solar radiation (see Fig. 2A, B). The experiments with solar radiation were performed in order to compare its inhibitory effects with those of our artificial UV-B radiation. Fig. 2A clearly shows that bacterial growth was only slightly more inhibited when exposed to solar radiation as compared to similar levels of artificial UV-B. The recover efficiency of samples exposed to solar radiation was higher, which might reflect higher rates of photorepair induced by UV-A under natural conditions (Fig. 2A, B) (Kaiser unpubl. data).

At radiation levels of $0.4 \mathrm{~W} \mathrm{~m}^{-2}$ bacterial density declines to ca $75 \%$ of the dark value within $6 \mathrm{~h}$ (Fig. 2A) and extracellular enzymatic activity exhibited a reduction to ca $60 \%$ of the dark value (Fig. 4). These radiation levels can be detected in the surface layer (up to $0.5 \mathrm{~m}$ depth) in the northern Adriatic Sea for about $3 \mathrm{~h}$ each day at least during summer (Fig. 1). Clearly, more measurements are needed to resolve the ecological role of UV-B in affecting bacterial growth in the surface layers of the ocean. The decline in extracellular enzymatic activity shown in Fig. 4 is probably a combined effect of photochemical degradation of bacterial nucleic acid and hence bacterial metabolism (shown in Fig. 2A) and cleavage of dissolved extracellular enzymes (Fig. 3). Mean total extracellular enzymatic activity was not significantly more retarded by UV-B than its dissolved fraction. As is true for bacterial production, extracellular enzymatic activity also increases again during dark incubations after exposure to UV-B (Fig. 5) indicating rapid recovery of bacterioplankton once they are mixed into deeper layers of the mixed water column.

Bacterial extracellular enzymatic activity is thought to be the main agent in processing and cleaving DOM (Chróst 1991). Almost all the incubations for bacterial production and extracellular enzymatic activity measurements are routinely performed in the dark or at low light conditions in the laboratory. This might lead to overestimations of the actual bacterial activity (i.e. production as well as extracellular enzymatic activity) in the surface layers of aquatic systems.

The microbial food web is the major route of organic carbon through aquatic ecosystems (Pomeroy \& Wiebe 1988). A changing physical environment such as the increase in global incident UV-B (Blumthaler \& Ambach 1990) due to the destruction of the ozone layer might most severely affect microbial life. The efficient recycling of nutrients within this 'microbial loop' has evolved for millions of years and we are just now learning to understand the principles underlying the complicated regulatory systems between DOM, heterotrophic bacteria and flagellates, and phytoplankton. UV-B is likely to influence all these compartments in different ways; predictions how the aquatic microbial food web might be altered by increased UV-B are currently impossible as too many uncertainties still exist. Only in-depth investigations focusing on the interactions between microbial compartments under different situations will allow us to predict whether or not severe changes in overall productivity in aquatic systems are likely to be expected when UV-B radiation increases.

Acknowledgements. This work was supported by the Austrian Science Foundation (grant 8608). Special thanks go to R. Kartusch for performing the measurements of the UV spectrum of the artificial light sources.

\section{LITERATURE CITED}

Akhlaq MS, Schuhmann HP, Sonntag C von (1990) Degradation of the polysaccharide alginic acid: a comparison of the effects of UV light and ozone. Environ Sci Technol 24: $379-383$

Azam F, Fenchel T, Field JG, Gray JS, Meyer-Reil LA, Thingstad $F$ (1983) The ecological role of water-column microbes in the sea. Mar Ecol Prog Ser 10:257-263

Backlund P (1992) Degradation of aquatic humic material by ultraviolet light. Chemosphere 25:1869-1878

Bailey CA, Neihof RA, Tabor PS (1983) Inhibitory effect of solar radiation on amino acid uptake in Chesapeake Bay bacteria. Appl environ Microbiol 46:44-49

Blumthaler $M$, Ambach W (1990) Indication of increasing solar ultraviolet-B radiation flux in alpine regions. Science 248:206-208

Cho BC, Azam F (1990) Biogeochemical significance of bacterial biomass in the ocean's euphotic zone. Mar Ecol Prog Ser 63:253-259

Chróst RJ (1991) Microbial enzymes in aquatic environments Springer Verlag, New York

Crutzen PJ (1992) Ultraviolet on the increase. Nature 356 104-105

Cullen JJ, Lesser MP (1991) Inhibition of photosynthesis by ultraviolet radiation as a function of dose and dosage rate: results for a marine diatom. Mar Biol 111:183-190

Cullen JJ, Neale PJ, Lesser MP (1992) Biological weighting function for the inhibition of phytoplankton photosynthesis by ultraviolet radiation. Science 258:646-650

Ducklow HW, Carlson CA (1992) Oceanic bacterial production. In: Marshall KC (ed) Advances in microbial ecology Plenum Press, New York, p 113-181 
Ducklow HW, Kirchman DL, Quinby HL, Carlson CA, Dam HG (1993) Stocks and dynamics of bacterioplankton carbon during the spring bloom in the eastern North Atlantic Ocean. Deep Sea Res 11:245-263

Ekelund NGA (1991) The effects of UV-B radiation on dinoflagellates. J Plant Physiol 138:274-278

Fuhrman JA, Azam F (1982) Thymidine incorporation as a measure of heterotrophic bacterioplankton production in marine surface waters: evaluation and field results. Mar Biol 66:109-120

Fuhrman JA, Sleeter TD, Carlson CA, Proctor LM (1989) Dominance of bacterial biomass in the Sargasso Sea and its ecological implications. Mar Ecol Prog Ser 57:207-217

Häder DP, Liu SM (1990) Effects of artificial and solar UV-B radiation on the gravitactic orientation of the dinoflagellate, Peridinium gatunense. FEMS Microbiol Ecol 73:331-338

Helbling EW, Villafañe V, Ferrario M, Holm-Hansen O (1992) Impact of natural ultraviolet radiation on rates of photosynthesis and on specific marine phytoplankton species. Mar Ecol Prog Ser 80:89-100

Herndl GJ, Müller-Niklas G. Frick J (1993) Major role of uitraviolet-B in controlling bacterioplankton growth in the surface layer of the ocean. Nature 361:717-719

Hobbie JE, Daley RJ, Jasper S (1977) Use of Nuclepore filters for counting bacteria by epifluorescence microscopy. Appl environ Microbiol 33:1225-1228

Hoppe HG (1983) Significance of exoenzymatic activities in the ecology of brackish water: measurements by means of methylumbelliferyl substrates. Mar Ecol Prog Ser 11 299-308

Jerlov NG (1950) Uitra-violet radiation in the sea. Nature 166:111-112

Karentz D, Boldwell ML, Coffin RB, Hanson A, Herndl GJ, Kilham SS, Lesser MP, Lindell M, Moeller RE, Morris DP, Neale PJ, Sanders RW, Weiler CS, Wetzel RG (1994) Impact of UV-B radiation on pelagic freshwater ecosystems: report of working group on bacteria and phytoplankton. Arch Hydrobiol Beih 43:31-69

Karentz D, Cleaver JE, Mitchell DL (1991) Cell survival characteristics and molecular responses of Antarctic phyto- plankton to ultraviolet-B radiation. J Phycol 27:326-341

Karner M, Herndl GJ (1992) Extracellular enzymatic activity and secondary production in free-living and marine snow associated bacteria. Mar Biol 113:341-347

Kieber DJ, McDaniel J, Mopper K (1989) Photochemical source of biological substrates in sea water implications for carbon cycling. Nature 341:637-639

Kieber DJ, Mopper K (1987) Photochemical formation of glycoxylic and pyruvic acids in seawater. Mar Chem 21: 135-149

Krupa SV, Kickert RN (1993) The greenhouse effect: the impacts of carbon dioxide $\left(\mathrm{CO}_{2}\right)$, ultraviolet-B (UV-B) radiation and ozone $\left(\mathrm{O}_{3}\right)$ on vegetation (crops). Vegetatio 104/105:223-238

Lee S, Fuhrman JA (1987) Relationships between biovolume and biomass of naturally derived marine bacterioplankton. Appl environ Microbiol 53:1298-1303

Mopper K, Stahovec WL (1986) Sources and sinks of low molecular weight organic carbonyl compounds in seawater. Mar Chem 19:305-321

Mopper K, Zhou X, Kieber RJ, Kieber DJ, Sikorski RJ, Jones RD (1991) Photochemical degradation of dissolved organic carbon and its impact on the oceanic carbon cycle. Nature 353:60-62

Pomeroy LR, Wiebe WJ (1988) Energetics of microbial food webs. Hydrobiologia 159:7-18

Seckmeyer G, McKenzie RL (1992) Increased ultraviolet radiation in New Zealand $\left(45^{\circ} \mathrm{S}\right)$ relative to Germany $\left(48^{\circ} \mathrm{N}\right)$. Nature 359:135-137

Smith RC (1989) Ozone, middle ultraviolet radiation and the aquatic environment. Photochem Photobiol 50:459-468

Smith SV, Buddemeier RW (1992) Global change and coral reef ecosystems. A Rev Ecol Syst 23:89-118

Tirlapur U, Scheuerlein R, Häder DP (1993) Motility and orientation of a dinoflagellate, Gymnodinium, impaired by solar and ultraviolet radiation. FEMS Microbiol Ecol 102 $167-174$

Worrest RC, Häder DP (1989) Effects of stratospheric ozone depletion on marine organisms. Environ Conserv 16: $261-263$ 